approaches to SSR can be pursued with comprehensive and principled objectives in mind: They need to be applied in phases that do not betray the eventual objectives of good SSG; honour local ownership of the process and its results; and take into account debilitating circumstances that require piecemeal rather than landslide approaches towards achieving the necessary buy-in and other supporting conditions, which in turn facilitate reasonably swift pursuits of even longer-term reform programmes and strategies.

Most importantly, helpful lessons (not necessarily "best practices") need to be generated to assist those involved in planning and embarking on new reform processes - and to advance the practical usefulness, political debate and academic scholarship on SSR as a technical, political and social process. While best practises of SSR planning and implementation are not widely assessed and discussed, past SSR activities should be studied more carefully. An evolving focus within the donor community on monitoring and evaluation of SSR activities and contributions is a positive sign, but only if such helpful feedback on applied SSR is used to facilitate honest learning and improvement.

If pursued as intended, SSR can play a constructive role in building legitimate states and safe societies. However, if only pseudo-SSR activities are pursued, the risk is great that good intentions result in more harm than good, illegitimate state institutions are strengthened and the peace, development and security dividends of transition processes - as well as affected beneficiary populations - will suffer as a consequence. Focussing on the basic principles and objectives of SSR should thus be the aim of all those committed to real and positive change in transition societies.

\title{
The EU Security Sector Reform Agenda: Between Democratic Security Governance and Internal Security Interests
}

\author{
Ursula C. Schroeder*
}

\begin{abstract}
The European Union has become deeply involved in international security sector reform (SSR) and security assistance efforts. This article examines the EU's activities in the field and discusses to what extent the EU has made good on the promises of its comprehensive SSR agenda in its external relations. To do so, it outlines the EU's diverging strategic goals in the field, maps the institutional arenas relevant to their implementation, and discusses three core challenges to the EU's activities: horizontal coordination across institutional arenas; vertical disconnects between the EU's strategic agenda and their implementation in the field; and larger political challenges that result from the coexistence of contradictory policy goals at the strategic level.
\end{abstract}

Keywords: European Union, Security Sector Reform, security assistance, Common Foreign and Security Policy, EU Internal Security Strategy

Europäische Union, Sicherheitssektorreform, Sicherheitshilfe, Gemeinsame Außen- und Sicherheitspolitik, EU-Strategie für innere Sicherheit

\section{Introduction}

$\mathrm{S}$ ecurity sector reforms (SSR) have become a prominent tool in the European Union's foreign policy repertoire: attempts to comprehensively reform or rebuild dysfunctional security sectors are now a crucial part of the EU's broader post-conflict stabilization and institution-building policies (see Council of the European Union 2003: 12; Council of the European Union 2008: 8). To support the reconstruction of effective and democratically governed security architectures in states in crisis or transition, the EU has engaged a wide range of civilian and military tools and instruments, both as part of its Common Security and Defence Policy (CSDP) and its broader conflict prevention and peacebuilding policies (see European Commission 2011;

* Dr. Ursula C. Schröder is Professor of International Security, Otto-SuhrInstitute for Political Science, FU Berlin.

This article has undergone a double-blind peer-review process.

The author would like to thank the anonymous reviewers and the editors for their valuable comments and suggestions.
Derks and More 2009 for overviews). Designed to foster specific international norms and standards concerning democratic oversight and control of the security sector, the EU's SSR activities are highly normative interventions that go beyond strengthening the technical capacities of a security sector. At the same time, however, the EU has also invested considerable resources into classical security assistance activities. Predominantly geared at enhancing the internal security of the Union, these measures build on security cooperation with non-member states to counter existing and emerging transnational threats that emanate from outside the EU's borders. Through political dialogue, strategic partnerships and agreements, the EU in particular seeks to enhance the crime-fighting, counter-terrorism and border management capacities of neighbouring states (see Council of the European Union 2010: 29f). This 'external dimension' of EU internal security policies has become particularly prominent in the context of the European Neighbourhood Policy and in the context of EU enlargement policies. 
The article examines the evolution of EU activities in the area of security assistance and SSR and shows that they have remained both horizontally and vertically fragmented. It further argues that - notwithstanding the EU's considerable achievements in building up its SSR capacities - EU activities continue to suffer from an underlying conflict between classical security assistance programmes, designed primarily to promote the EU's own internal security interests, and comprehensive SSR activities aimed at fostering the good governance and democratic oversight of security sectors in partner countries.

\section{The EU's Strategic Agendas: Diverging Approaches}

SSR is "not a new area of engagement for the European Union" (European Commission 2006b: 3). Particularly police and justice reforms have been part and parcel of different EU foreign policies for a long time (see Hänggi and Tanner 2005; European Commission 2006a for overviews). The publication of two strategy papers on the European Community's and the European Security and Defence Policy's (ESDP) contributions to SSR (Council of the European Union 2005a, European Commission 2006b) was a first attempt to focus and streamline the EU's diverse range of activities in this field. Squarely placing its understanding of SSR into the international reform discourse led by the OECD's Development Assistance Committee, the EU has taken a people-centred and holistic approach to SSR that reflects the observable larger shift towards human security concepts in international development discourses. Echoing the OECD's widely accepted definition, EU SSR activities aim to "increase... the ability of a state to meet the range of both internal and external security needs in a manner consistent with democratic norms and sound principles of good governance, human rights, transparency and the rule of law" (Council of the European Union 2005a: 9, see similar OECD DAC 2005: 11). A report by the UN Secretary General similarly summarises the ambitious goals of the international SSR agenda as follows: "security sector reform has ... as its goal the enhancement of effective and accountable security for the State and its peoples without discrimination and with full respect for human rights and the rule of law" (United Nations 2008: 6).

In parallel to this aim of fostering democratic security governance through SSR, internal security interests have become central aspects of the EU's foreign policies towards its neighbourhood and further afield. Instead of prioritising the creation of strong mechanisms of democratic control, accountability and good governance of security sectors, the EU here promotes classical forms of security cooperation in order to strengthen the counter-terrorism, counter-crime and border control capacities of partner countries' security sectors. In particular, in the conclusion of stabilisation and association agreements and strategic partnerships with states in the EU's Southern and Eastern neighbourhood, the externalization of EU internal security interests has started to play a large role. This second, and potentially countervailing, strategic goal was first set out in the strategy on the 'External Dimension of Justice and Home Affairs' (Council of the European Union 2005b) and has been clearly expressed in major Justice and Home Affairs (JHA) strategy papers during the past decade. In particular after the terror attacks of September $11^{\text {th }}, 2001$, in New York and the attacks of March $3^{\text {rd }}, 2004$, in Madrid, internal security strategies targeting the EU's Southern neighbourhood moved into the focus of Justice and Home Affairs policymakers (e.g. the 2002 Valencia Plan). The subsequent Hague Programme for Justice and Home Affairs (2004) and the External Dimension of Justice and Home Affairs (2005) strategy continued to stake out the claims of internal security actors in the field of EU external security assistance policies. To improve the internal security of the Union, for instance the Hague Programme specifically called for increases in the funding for counterterrorism related capacity-building projects in third countries (Council of the European Union 2004: 21). Similarly, the Strategy on the External Dimension of JHA stressed the need to build judicial and police capacities in third countries in order to respond to the needs of EU citizens (Council of the European Union 2005b: 7). Prioritising the export of law enforcement capabilities to the EU's neighbourhood, this second policy agenda focuses more on improving the effectiveness of security sectors than on strengthening their democratic governance. It is summarized in the EU's 2010 Internal Security Strategy (ISS). This strategy promotes a global approach to security that closely integrates internal and external security policies and that includes core internal-security related priorities in EU dialogues with third countries and regional organizations (see further Council of the European Union 2010: 29f.; European Commission 2010: 3).

\section{The EU as an Actor: Policy Fields and Institutions}

The EU's strategic approach to SSR is explicitly based on the conviction that it has "the capacity to take a holistic approach in supporting security sector reform" and that it is "uniquely placed to bring together a wide range of civilian and/or military activities needed in the framework of SSR" (Council of the European Union 2005a: 10). However, SSR and security assistance activities remain dispersed across the EU's security architecture (see Derks and More 2009; Gross 2013 for extended overviews). Most visibly, the majority of the EU's recent and ongoing crisis management operations have been mandated to foster police and defence reforms in recipient states. As part of the EU's Common Security and Defence Policy (CSDP), these operations mostly assist individual actors within a security sector. For example, the ongoing EU police and military operations in the Democratic Republic of Congo seek to advise and assist the Congolese police and defence establishment in reforming the security sector; the EU training missions in Mali and Somalia provide military training to the Somali National Armed Force and the Malian Armed Forces; the EU's EUPOL COPPS mission in the Palestinian Territories mentors the Palestinian Civil Police; EULEX Kosovo and EUJUST Lex Iraq are involved in the reform of the Kosovar and Iraqi legal systems, while the EU police mission in Afghanistan tries to reform the Afghan civil policing 
arrangements. The institutional structures that oversee and organize the deployment of these CSDP operations remain in flux. After 2009, the Treaty of Lisbon created a set of posts and institutional bodies that have partially replaced - or that have been merged with - the EU's previous external relations architecture. The new institutional structure aims to focus and streamline the EU's external relations competences; it is centred on the new post of High Representative of the Union for Foreign Affairs and Security Policy and its supporting body, the European External Action Service (EEAS). Within the EEAS, the Crisis Management Planning Directorate (CMPD) strategically plans the EU's civilian and military operations, while their operational planning and conduct is carried out either by the Civilian Planning and Conduct Capability (CPCC) or by the EU's Military Staff.

Much less in the public eye than the highly visible CSDP operations, the European Commission has slowly incorporated more and more security-relevant aspects into its external assistance programmes in recent years. Commission-financed activities have included large-scale security and justice assistance programmes as part of the EU's development policies, as well as technical assistance and support to criminal justice and police institutions in the EU's neighbourhood. An early initial mapping showed that Commission funding has been used in over 70 countries worldwide to support SSR processes (European Commission 2006b: 6). A more recent external evaluation of European Commission support puts its justice and security system reform (JSSR) budget in the years 2001-09 at EUR 1 billion, with yearly support increasing from EUR 14 million in 2001 to EUR 174 million in 2009 and 105 countries benefitting from JSSR-related interventions (see further European Commission 2011: 7). This is a major change in the Commission's approach to external assistance. Only a few years ago, the EC's development policies were focused almost exclusively on traditional development cooperation and crisis prevention that, in terms of security assistance, mainly featured isolated technical assistance projects to weak and dysfunctional security sectors in recipient states. Today, several Directorates-General (DGs) share responsibility for the development of SSR-related and security assistance programmes. Based on the premise that "security and development are interdependent and mutually reinforcing" (DG Development and Cooperation n.d.), DG Development and Cooperation/Europe Aid carries out a variety of SSR assistance projects in the context of its broader development policies. In addition, the new DG Service for Foreign Policy Instruments (FPI) operationally manages Commission foreign policy actions such as those financed by the Instrument for Stability (IfS). This budget line is a further point of departure for the European Commission: designed to bridge the EU's security and development policies, the IfS has enabled the Commission to intensify its crisis management and securityrelated activities. As only one example, IfS funding in 2013 included a EUR 20 million aid package for Mali that, among other things, was designed to support Mali's domestic justice system and its law enforcement services. Outside the Commission's development and crisis management policies, DG Enlargement deals with all aspects of EC policy towards acceding and candidate states. Here, assistance to reforming their security and justice sectors makes up a large part of the process of aligning candidate states' legal and political systems with the EU acquis. Finally, the 'external dimension' of EU Justice and Home Affairs primarily aims to enhance the efficiency and effectiveness of neighbouring states' security sectors. In this context, the EU's comprehensive SSR strategies have not played a major role, with classical security assistance - e.g. training and infrastructure provision in the area of border management and counter-terrorism clearly taking precedence. For the case of the Mediterranean region, Monar (2008: 134) and others (e.g. Wolff 2009; Joffé 2008) agree that EC reforms have been targeted primarily at capacity building in the fight against illegal immigration and cross-border crime with a focus on drug trafficking and terrorism. Thus, EU Justice and Home Affairs policies remain "very closely related to the EUs internal security objectives and priorities" (Monar 2008: 135), instead of taking its wider SSR agenda into account (see Ryan 2009, Monar 2010 for a more extensive discussion).

\section{Evaluation: Persistent Institutional and Political Challenges}

Over the past decade, the European Union has conducted a wide variety of security-related assistance projects and operations around the world that, taken together, have made the EU a crucial international player in the field. However, the Union has struggled both to overcome the horizontal and vertical fragmentation of its institutional architecture and to integrate its activities into a coherent set of political and strategic objectives.

First of all, the EU faces institutional challenges in the areas of SSR and security assistance that echo previous assessments of EU foreign and security policies in other fields. Although the EU's system of external security governance has undergone a near continuous process of transformation during the past decade, core fault lines continue to run through its institutional architecture. For one, its security architecture continues to be a fragmented structure made up of different institutional arenas. Among them, conflicts over competences are systematic rather than accidental. In particular, the weak delimitation of competences between the EU's longer-term conflict prevention and peacebuilding policies and its shorter-term crisis management operations has led to sometimes fierce and protracted inter-institutional conflicts between the Commission and the Council (see e.g. Sicurelli 2008; Van Voren 2009). These inherent flaws in the EU's organizational architecture have resurfaced in the case of SSR: frictions among the EU's institutions result from the fact that SSR-related initiatives can fall under both a Commission and a Council lead. As a consequence, the EU'S various SSR-related activities in a partner country have often been planned separately by Commission DGs and CSDP actors. As a result, different sets of actors engaged in the EU's external relations have pursued diverging policies with regard to SSR and security assistance: while the comprehensive SSR concept enjoyed some standing in the development and crisis management communities of 
the European Union, for instance EU services dealing with Justice and Home Affairs or EU Enlargement issues did not incorporating the SSR strategies into their programming. As EU practitioners in these fields observed, the development of the EU's SSR concepts did not generate a very lively debate at the time (Conversation in European Commission, May $14^{\text {th }}$ and $\left.29^{\text {th }}, 2009\right)$. As a consequence, in particular the EU's internal security assistance policies have remained divorced from the broader governance-oriented goals enshrined in the EU's SSR strategy.

Even after the integration of many foreign policy competences into the European External Action Service after 2010, some of the old inter-institutional conflicts persisted. Observers still highlight "confusion and conflict within the halls of EU bodies" (Smith 2013: 1300) and point to problems with the institutional design of the EEAS that combines Council and Commission expertise. Although the EEAS's structure has undergone a continuous process of reforms since its inception in late 2010, progress has been mostly "on paper in the form of regular new 'organigrammes' describing the EEAS structure, but little progress in reality" (ibid: 1307; see also Vanhoonacker and Pomorska 2013). A recent study by the European Parliament's Subcommittee on Security and Defence agrees that "the EEAS remains an organizational culture in the making and the joining up of different organizational cultures - Commission, Council and member state - has predictably been marked by teething problems" (Gross 2013: 27).

In addition to the horizontal fragmentation of EU activities in the field, the vertical disconnect between the EU's strategic concepts and their implementation in the field presents a persistent challenge. So far, the influence of EU SSR strategies on field-level programmes and practices has remained limited. Both the Council and the Commission have struggled with operationalizing the comprehensive, but relatively generic, SSR strategies. Although actors across all involved institutional arenas broadly agree on the need for those strategies - the EU had developed a "good framework" for SSR (Conversation in Council, May $\left.8^{\text {th }}, 2009\right)$, with its strategies "all in place" (Conversation in the European Commission, May $28^{\text {th }}, 2009$ ) the EU's SSR concepts have so far been used at most as "general guidelines" (Conversation in the Council, May 14th, 2009). And although the EU's cross-pillar and holistic approach to SSR "is happening at the strategic level" (ibid.), "what is missing is the implementation" (Conversation in the European Commission, May $\left.28^{\text {th }}, 2009\right)$. As a result, EU SSR projects and operations for specific partner countries often do not reflect the holistic and integrated character of EU strategies. Instead, they are not only developed separately, they are also "not designed in conformity with an overall EU SSR-support strategy for the particular partner country, which addresses the security sector as a whole" (Derks and More 2009: 22). The case of EU security assistance in the Democratic Republic of Congo (DRC) is only one example of this vertical disconnect between strategies and programmes. As Justaert and Keukeleire (2010: 14-5) outline, three of the five EU missions in the DRC could be classified as SSR missions in the comprehensive understanding of the concept (EUSEC RDC, EUPOL Kinshasa and EUPOL RDC). Mandated to monitor, mentor, advice and train the Congolese police and military services, they were complemented by REJUSCO, a large-scale Commission programme aimed at the reform of the Congolese judicial sector. In practice, however, these activities were pursued in parallel, instead of in an integrated manner. External actors in the field "made little reference to - or where wholly unaware of - an overarching common strategy for supporting SSR in the DRC" (More and Price 2011: VI). As a result of this lack of vertical tight coupling between the EU's overarching strategies and their implementation, EU actors were able "to pursue their own agendas" (ibid.) without much regard to overarching goals.

The outlined persistent fragmentation and institutional subdivision of the EU's complex system of security governance has enabled different EU actors to pursue potentially incompatible security assistance policies in parallel. In particular the division into internal security interests on the one hand and the goal of fostering democratic security governance on the other has remained problematic. This coexistence of diverging strategic goals in the EU's security assistance policies results in part from the outlined horizontal and vertical fragmentation of the EU's security architecture. However, conflicts between the different agendas have not materialized to the extent that could be expected. While a 'normal' amount of conflicts over competences between the Council's CSDP architecture and the Commission's development actors persisted in the "grey area" of SSR (Conversation in the Commission, May 27 h, 2009), little political controversy has erupted about the diverging norms and strategic ends of EU security sector support. Instead, internal security-oriented programmes and SSR have so far often been implemented in parallel without much interaction or coordination. Incompatible goals were effectively buffered from each other by an architecture that continues to favour line-based organizational solutions over horizontal exchange and coordination. And although the EU acknowledges the necessarily interdependent nature of its different SSR-relevant policies in its strategy papers, the organizational units tasked with actual programme- and mission-development are linked by only very few formal horizontal ties. This loose coupling of different EU policy arenas has contributed to diffusing latent conflicts about the EU's diverging goals in the field of security assistance.

\section{Trends and Recommendations}

Overall, this article has shown that EU activities in the field of SSR and security assistance remain fragmented both along institutional divides and in terms of their substance. Therefore, although the EU is in principle well equipped to implement a truly comprehensive approach to SSR, it has not fully done so. Instead, the EU's performance has been hampered by unresolved contradictions between its diverging strategic goals and institutional interests. What is more, two further trends point to the decreasing, rather than increasing, relevance of comprehensive approaches to SSR in the EU's foreign relations.

First of all, SSR has in some cases simply become a new label used by EU actors to refer to a large range of security-relevant assistance practices, some of which fall outside the goals of 
comprehensive SSR. In some instances, the SSR concept has essentially been used to re-label the EU's pre-existing assistance programmes in the area of internal security. For instance EC technical assistance projects in the fields of judicial and police reform have been declared part of both the wider SSR agenda and the narrower internal security agenda: overviews of the EC's contribution to counter-terrorism capacity building (see European Commission 2004) incorporate the same EC budget lines and project fiches as the EC's own mapping of its holistic SSR activities (see European Commission 2006a). Similarly, Youngs (2008: 434) found that in practice, "assistance provided under a SSR label still includes much traditional defence diplomacy. Security cooperation incorporating good governance elements has focused far more on enhancing the efficiency rather than accountability of armed forces in developing states."

A second trend highlights that the practical relevance of SSR concepts in the EU's CSDP operations is in decline. A look at the mandates of the most recently established CSDP operations showcases that the EU has increasingly turned away from the broader democratic governance and oversight goals enshrined in its SSR concepts: ${ }^{1}$ as a first example, EUCAP Nestor (2012-ongoing) is mandated to assist host countries in the Horn of Africa to strengthen their maritime capacities, in particular in the area of counter-piracy operations. The very limited mandate of EUAVSEC South Sudan (2012-2014) sought to assist the South Sudanese government in strengthening aviation security at Juba International Airport. EUCAP Sahel Niger (2012-ongoing) - a training mission to combat terrorism and organized crime in Niger - as well as EUBAM Libya (2013-ongoing) - mandated to support the Libyan authorities in developing their border management capacities - primarily follow EU internal security interests. The EU's military training missions in Somalia (EUTM Somalia, 2010-ongoing) seeks to strengthen Somali military capacities by training its armed forces. Finally, also the case of recent CSDP engagement in Mali (EUTM Mali 2013-ongoing) serves as an example of the outlined disconnect between the EU's own security interests and its broader democratic governance and development goals: EUTM Mali predominantly focuses on providing basic training for combat units in the Koulikoro training camp in Mali. It thus primarily contributes to the EU's interest in stabilizing a volatile state and region, but offers very little in terms of fostering democratic security governance. In fact, none of the recently deployed CSDP operations base their mandates on the EU's comprehensive SSR concept. Instead, they primarily focus on strengthening recipient state security institutions in the interest of the EU's internal security or stabilization goals. The EU has thus included only very few 'genuine' SSR activities into its CSDP operations.

In sum, the EU has so far not fully implemented its comprehensive SSR strategy. In a recent development, however, EU actors from different institutional arenas have joined forces to foster a comprehensive EU approach to the field of crisis management more generally. In late 2013, a Joint Communication from the European Commission and

1 See http://www.csdpmap.eu/mission-chart for an overview of current CSDP operations. the High Representative for Foreign Affairs and Security Policy outlined the need to enhance the comprehensiveness of the EU's approach to external conflict and crises. Committed to improving horizontal coordination and cooperation in the fields of conflict prevention and crisis resolution, the Joint Communication sets out a set of concrete steps to improve the EU's external action that, if implemented, will also have repercussions for its SSR activities. This development clearly points in the right direction. As part of this process the EU should also seize the opportunity to reinvigorate its normative goal of using its SSR activities to "contribute to an accountable, effective and efficient security system, operating under civilian control consistent with democratic norms and principles of good governance, transparency and the rule of law, and acting according to international standards and respecting human rights" (Council of the European Union 2005a: 4). So far, the EU's preference for classical security assistance has led to the neglect of the potentially negative consequences of strengthening the defence and internal security capacities of partner countries. Security assistance activities are in fact always highly political processes that intervene deeply into the domestic political fabric of states receiving assistance. Therefore, the EU's primary focus on its own internal security and stabilization interests has opened it up to the risk of losing track of these larger - and potentially detrimental - implications of its security assistance policies for the domestic political systems and the citizens of the recipient states themselves.

\section{Bibliography}

Council of the European Union (2003) European Security Strategy. A Secure Europe in a Better World. Brussels: 12.12.2003.

--- (2004) The Hague Programme: Strengthening Freedom, Security and Justice in the European Union. 16054/04. Brussels: 13.12.2004.

--- (2005a) EU Concept for ESDP Support to Security Sector Reform (SSR). 12566/4/05. Brussels: 13.10.2005.

--- (2005b) A Strategy for the External Dimension of JHA: Global Freedom, Security and Justice. 15446/05. Brussels: 06.12.2005.

--- (2008) Report on the Implementation of the European Security Strategy. Providing Security in a Changing World. S407/08. Brussels: 11.12.2008.

--- (2010) Internal Security Strategy for the European Union: Towards a European Security Model. Brussels: 25./26.03.2010.

Derks, Maria and More, Sylvie (2009) The European Union and Internal Challenges for Effectively Supporting Security Sector Reform. The Hague: Clingendael.

DG Development and Cooperation (no year) Security and Conflict. Brussels: European Commission, http://ec.europa.eu/europeaid/ what/security-conflict/index_en.htm.

European Commission (2004) Non-Paper External Action in the Fight Against Terrorism. The Commission's Counter-Terrorism Technical Assistance Strategy. Brussels: 08.09.2004. 
--- (2006a) Annexes to the Concept for European Community Support for Security Sector Reform. SEC(2006) 658. Brussels: 24.05.2006.

--- (2006b) A Concept for European Community Support for Security Sector Reform. COM(2006)253 final. Brussels: 24.05.2006.

--- (2010) Communication from the Commission: The EU Internal Security Strategy in Action. Five steps towards a more secure Europe COM(2010) 673 final. Brussels: 22.11.2010.

--- (2011) Thematic Evaluation of the European Commission Support to Justice and Security System Reform. Final Report. Volume I - Main Report. November 2011. Brussels: European Commission.

European Commission and High Representative for Foreign Affairs and Security Policy (2013) Joint Communication on the EU's Comprehensive Approach to External Conflict and Crises. JOIN(2013) 30 final. Brussels: 11.12.2013.

Gross, Eva (2013) Assessing the EU's Approach to Security Sector Reform (SSR). Study for the Policy Department, DirectorateGeneral for External Policies of the Union. Brussels: European Parliament.

Hänggi, Heiner and Tanner, Fred (2005) Promoting Security Sector Governance in the EU's Neighbourhood. Chaillot Paper No. 80. Paris: EU Institute for Security Studies.

Joffé, George (2008) The European Union, Democracy and Counter-Terrorism in the Maghreb, in: Journal of Common Market Studies, 46 (1): 147-171.

Justaert, Arnout and Keukeleire, Stephan (2010) The EU's Security Sector Reform Policies in the Democratic Republic of Congo, in: European Integration online Papers (EIoP), 14 (Special Issue 1): http://eiop.or.at/eiop/texte/2010-006a.htm.

Monar, Jörg (2008) Justice and Home Affairs: Security Sector Reform Measures as Instruments of EU Internal Security Objectives, in: Spence, David and Fluri, Philipp H. (eds.) The European Union and Security Sector Reform. London: John Harper Publishing, 126-140.

--- (2010) The EU's Externalisation of Internal Security Objectives: Perspectives after Lisbon and Stockholm, in: The International Spectator, 45 (2): 23-39.

More, Sylvie and Price, Megan (2011) The EU's Support to Security System Reform in the Democratic Republic of Congo: Perceptions from the Field in Spring 2010. The Hague: Clingendael.

OECD DAC (2005) Security System Reform and Governance - A DAC Reference Document. Paris: OECD Development Assistance Committee.

Olsen, Gorm Rye (2009) The EU and Military Conflict Management in Africa: for the Good of Africa or Europe? In: International Peacekeeping, 16 (2): 245-260.

Ryan, Barry J. (2009) The EU's Emergent Security-First Agenda: Securing Albania and Montenegro, in: Security Dialogue, 40 (3): 311-331.
Sicurelli, Daniela (2008) Framing Security and Development in the EU Pillar Structure. How the Views of the European Commission Affect EU Africa Policy, in: European Integration, 30 (2): 217-234.

Smith, Michael E. (2013) The European External Action Service and the Security-Development Nexus: Organizing for Effectiveness or Incoherence? In: Journal of European Public Policy, 20 (9): 1299-1315.

United Nations (2008) Securing Peace and Development: the Role of the United Nations in Supporting Security Sector Reform. Report of the Secretary General. S/2008/39. New York: 23.01.2008.

Vanhoonacker, Sophie and Pomorska, Karolina (2013) The European External Action Service and Agenda-Setting in European Foreign Policy, in: Journal of European Public Policy, 20 (9): 1316-1331.

Van Vooren, Bart (2009) EU-EC External Competences after the Small Arms Judgment, in: European Foreign Affairs Review, 14 (1): 7-24.

Wolff, Sarah (2009) The Mediterranean Dimension of EU Counter-Terrorism, in: Journal of European Integration, 31 (1): 137-156.

Youngs, Richard (2008) Fusing Security and Development: Just Another Euro-Platitude? In: Journal of European Integration, 30 (3): 419-437.

\section{Machtübergänge friedlich managen!}

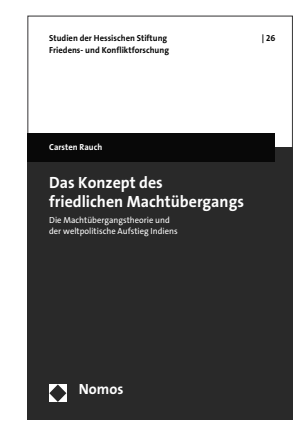

Das Konzept des friedlichen Machtübergangs

Die Machtübergangstheorie und der weltpolitische Aufstieg Indiens

Von Carsten Rauch

2014, 487 S., brosch., 89,- -€

ISBN 978-3-8487-1370-7

(Studien der Hessischen Stiftung Friedens- und

Konfliktforschung, Bd. 26)

www.nomos-shop.de/22629

Bestellen Sie jetzt telefonisch unter 07221/2104-37. Portofreie Buch-Bestellungen unter www.nomos-shop.de
X Nomos 